\title{
Aleš Havlíček \\ (1956-2015) \\ in memoriam
}

JAKUB JINEK

At the end of last May, Francisco Lisi told me that Hans Krämer, the distinguished Platonic scholar and the founding figure of the Tübingen School of Platonic scholarship, had passed away a month ago, and added: "This is a black year for all Platonists". Lisi thus referred to the fact that Giovanni Reale, Krämer's fellow-worker in the field of Platonic hermeneutics and the founder of the Milan school of Platonic scholarship, had also died only some six months before that. At the time, nobody could suspect that the black year was to culminate in less than two month's time, on 22th July 2015, when, suddenly and quickly, our colleague and close friend Aleš Havlíček also died.

Like Krämer and Reale, Aleš also founded a school which has won academic acclaim. A fitting name for it, I suggest, would be the Prague Neoclassical School of Political Thought. It has drawn substantively on the work of the founders of the German-American neoclassical school, L. Strauss and H. Arendt, and it agreed with their main thesis that the disaster of the Nazi and Communist totalitarian regimes (Aleš had very direct personal experience with the latter one, as the Communists dismissed him from the university and made him to work as a mechanic for almost a decade) are rooted in the crisis of modern European rationality, so that in order to tackle this crisis, Europe should concentrate on its pre-modern period and seek inspiration in the classical works of ancient and medieval philosophical tradition. Aleš enriched this intuition by two important innovations. First, in accord with Czech authors such as 
Emanuel Rádl, Jan Patočka and Ladislav Hejdánek, he systematically insisted that many of the practical philosophical problems which we face today present an important spiritual aspect which should - in a somewhat "biblical" manner - orient us to the future. Secondly, with a more historical accent, Aleš recognized that a true revival of the classical tradition necessitates a close and rigorous study of its authors and works. This was the reason why he dedicated much of his academic effort to research on Plato - and he achieved here a level of expertise that the founders of the neoclassical school hardly ever had.

In Platonic hermeneutics, Aleš was influenced by what we can call the anti-dogmatic strand of interpretation of Platonic philosophy, represented by Leo Strauss on one hand and Theodor Ebert on the other. At the same time, however, he fully respected the one approach which is usually taken to be the most dogmatic one - that of Tübingen and Milan. In this openmindedness, which was characteristic for him, Aleš could remind us of Jan Patočka, who similarly oscillated between the systematical inclination to an existential, rather non-dogmatic interpretation of Platonism, and his historical-philological expertise which made him, one he familiarized himself with the works of Gaiser and Krämer, to entirely adopt their hermeneutical view.

Aleš's philosophical interest in Plato concentrated on the Good. The Good was for him non-objective, surpassing any positive conceptualization, being - in a rather Kantian way - something regulative and merely guiding our practice in the plurality of its empirical conditions. The Good can be grasped, not by any positive science, but only by dialectics as an activity of the rational soul, inspired by the virtue of phronesis. Dialectics finds its expression in dialogue that helps to articulate and differentiate correct and incorrect views. Dialectics always comprises conflicting views; negativity belongs essentially to thought itself. However, there is a positive way out of this essential conflict of opinions, one which is not based merely on arguments but rather on a 
decision. Following Weischedel, Aleš often spoke about the basic decision, by which the individual person relates to the Divine or - using a Platonic metaphor - by which she is forced towards the Good. For Aleš, the crucial point was that this basic decision has a practical character and intention. On his rather radical reading of Plato's myth of the cave, theoretical philosophy in sense of ascending towards the Good is but a presupposition for the descent inside the cave, i.e. politics which comprises all efforts of theory and is consequently superior to it.

But let me get back from the ideas to the personal memories. The conversation with F. Lisi I mentioned at the outset occurred in Ústí nad Labem at a conference of the Collegium Politicum, organized by Aleš as the Dean of the Faculty of Arts. It was a very stimulating meeting intellectually, and furthermore, Aleš imprinted it with his optimism, generosity, and friendship, putting into practice the title of the conference: koina ta ton philon - "for friends, all is shared". As an organizer of numerous conferences and meetings (prominently including the international Plato's symposia, held biannually in Prague), Aleš always insisted that it is not enough to simply let scholars read their papers; he wanted each conference to be also a social event which can strengthen the sense of community and the bonds of personal friendship among the participants.

Aleš had a tremendous talent to connect people across fields, professions, languages and differences of age. The force of his personal field brought together established academics and service staff, business people and members of the Prague cultural underground, professors and undergraduates; with all of them he talked in the same tone, without any trace of haughtiness. That was the reason why he was so popular among students, and some of them loved to make long trips with him for the notorious "road seminars", often with lack of material comfort but always with the immense reward provided by reading Empedocles in Akragas, Machiavelli in Florence and Heidegger in Todtnauberg. 
Free of all arrogance, he was always prepared to help by giving advice or providing some service to others - generations of students and colleagues profited from his tireless willingness to read, edit and correct their texts. Aleš run the most important Czech editing house for philosophy; this was a vocation which he inherited from the Samiztat-era and which required him to a fair extent to sacrifice his own work. He did it with ease, professing that it felt natural; quoting Aristotle, he claimed that the whole is more fundamental than its parts.

In many respects, Aleš was a magnanimous man in the Aristotelian sense. The loss of such a $\mu \epsilon \gamma a \lambda o \psi v$ xos is indeed irreparable for both Czech and international academic community. Yet for him personally, from his Platonic and Christian perspective, his death is not the end but rather the fulfillment of a life which has always been lived with respect to "that which is coming from the future". 